\title{
Reproduction of Didymella bryoniae on Nine Species of Cucurbits Under Field Conditions
}

\author{
Anthony P. Keinath, Coastal Research and Education Center, Clemson University, Charleston, South Carolina, 29414-5329 USA
}

\begin{abstract}
Keinath, A. P. 2014. Reproduction of Didymella bryoniae on nine species of cucurbits under field conditions. Plant Dis. 98:1379-1386.

Eighteen cucurbit cultivars representing 5 genera, 9 species, and 11 taxa susceptible to gummy stem blight were inoculated with Didymella bryoniae in field plots in Charleston, SC, in autumn 2008, autumn 2009, and spring 2011 to determine the suitability of the hosts and various plant parts for formation of sexual and asexual fruiting bodies of the pathogen. In 1, 2, or 3 years, D. bryoniae reproduced on all 18 cultivars, on leaves, and on all plant parts examined-pedicles, peduncles, petioles, tendrils, and vines. Watermelon and citron (both Citrullus lanatus) and melon (Cucumis melo) had significantly more leaves with fruiting bodies than cucumber (Cucumis sativus), bottle gourd

(Lagenaria siceraria), and eight cultivars of squash and pumpkin $(\mathrm{Cu}$ curbita maxima, C. moschata, and C. pepo). On plant parts other than leaves, melon had the greatest proportions of tissue pieces with fruiting bodies, and citron had the least. Fruiting bodies were observed on $86 \%$ of plant parts examined in autumn 2009 but on only $28 \%$ in spring 2011, when environmental conditions were hot and dry. In 2009, pseudothecia and pycnidia were found in equal proportions on leaves, but pseudothecia were found more frequently than pycnidia on leaves in 2011 and on other plant parts in 2009 and 2011.
\end{abstract}

The cucurbit disease gummy stem blight, caused by the ascomycete Didymella bryoniae (Auersw.) Rehm (=Stagonosporopsis cucurbitacearum (Fr.) Aveskamp, Gruyter \& Verkley), is present in all regions of the world where cucurbits are grown $(13,22)$. Gummy stem blight causes serious losses on watermelon (Citrullus lanatus (Thunb.) Matsum. \& Nakai) $(1,9,10)$, muskmelon ( $\mathrm{Cu}$ cumis melo L.) $(12,29,32)$, and cucumber $($ C. sativus L.) $(3,21,31)$. Summer squash (Cucurbita pepo L.) and butternut squash (C. moschata Duch. ex Poir) are less susceptible to gummy stem blight than watermelon, muskmelon, or cucumber $(15,27)$.

D. bryoniae overwinters on cucurbit debris. The fungus remains viable for less than 1 year in northern climates and up to 2 years in semitropical climates $(2,11,12,31)$. At the beginning of the growing season, D. bryoniae may produce pycnidia (asexual fruiting bodies containing hundreds of conidia each) or pseudothecia (sexual fruiting bodies containing dozens of ascospores each) on host debris remaining from previous crops to initiate a new disease cycle $(2,11,31)$. Free moisture on infested debris and an air temperature $>5^{\circ} \mathrm{C}$ are necessary for formation of fruiting bodies (31). Conidia are dispersed mainly within the plant canopy (25). Ascospores are released into the air and have been trapped above field-grown watermelon and greenhouse cucumber plants after symptoms appeared (25,31). A few ascospores were trapped year-round in Florida; they were thought to arise from watermelon debris left in fields abandoned after harvest (25).

D. bryoniae is homothallic (22). Both pycnidia and pseudothecia are produced on hosts commonly affected with gummy stem blight, i.e., watermelon, melon, and cucumber. Chester (1), in the first report of gummy stem blight on watermelon, mentioned pyc-

\section{Corresponding author: A. P. Keinath, E-mail: tknth@clemson.edu}

This material is based upon work supported by NIFA/USDA under project number SC-1700446. Technical Contribution No. 6238 of the Clemson University Experiment Station.

* The $\boldsymbol{e}$-Xtra logo stands for "electronic extra" and indicates that Figure 1 appears in color online.

Accepted for publication 16 April 2014.

http://dx.doi.org/10.1094/PDIS-02-14-0139-RE

(C) 2014 The American Phytopathological Society nidia on leaves, petioles, tendrils, and vines. Subsequently, both pseudothecia and pycnidia were observed on crowns of watermelon, and pseudothecia also were found on tendrils and petioles; on leaves, pycnidia were more common than pseudothecia (25). On muskmelon, pycnidia were observed on seedlings and leaves, pseudothecia were observed on petioles, and pseudothecia and pycnidia were observed on vines $(5,7,28,29)$. Both types of fruiting bodies also have been found on cucumber vines and peduncles (fruit stems) left on plants after harvest $(3,31)$. Although the occurrence and type of fruiting bodies have been reported for several commonly cultivated cucurbits, the frequency and density of fruiting bodies were not quantified. Differences in frequency of pseudothecia may impact epidemic progress, distribution of diseased plants, and spread of the pathogen $(25,31)$.

Considerably less information is available about reproduction of D. bryoniae on other cucurbit hosts that are less susceptible to gummy stem blight than watermelon, muskmelon, and cucumber $(2,5,15,27)$. Smith (28) found pycnidia on leaves of pumpkin and yellow crookneck summer squash (both Cucurbita pepo L.) and pseudothecia on squash stems. Grossenbacher (5) inoculated vines and found pycnidia and pseudothecia on squash (C. maxima Duch. ex. Lam.), pseudothecia on pumpkin and bottle gourd (Lagenaria siceraria (Molina) Stand.), and no fruiting bodies on smooth loofah (Luffa aegyptica (L.) M.J. Roehm). Chiu and Walker (2) found fruiting bodies (type not reported) of $D$. bryoniae on Hubbard squash (C. maxima) that had been inoculated in the field, and Jensen et al. (8) observed pycnidia on inoculated stems of $C$. maxima seedlings. Most studies, other than the inoculations done by Grossenbacher (5) and Chiu and Walker (2), included fewer than five horticultural types of cucurbits in one experiment. In addition, it is unknown if, and which, fruiting bodies occur on petioles, tendrils, or other parts of Cucurbita, Lagenaria, and Luffa species. Although only small acreages of smooth loofah and bottle gourd are grown, there is a larger potential market for both crops with Asian and Hispanic consumers on the East Coast of the United States (4).

Pathogen reproduction drives polycyclic epidemics. Gummy stem blight is a polycyclic disease with typical sigmoidal disease progress curves $(9,10)$. Ascospores and conidia are produced during disease cycles $(21,22,25)$. In a previous paper, I reported that melon and watermelon foliage were more susceptible to gummy stem blight than squash and pumpkin foliage (15). The question remains whether $D$. bryoniae also reproduces to a greater extent on 
more susceptible hosts than on less susceptible hosts. Reproduction by $D$. bryoniae on a variety of cucurbit species has not been examined on a large scale under field conditions. The objectives of this study were to (i) compare the ability of major horticultural types of cucurbits cultivated in the United States to serve as reproductive hosts of D. bryoniae; (ii) compare reproduction of the pathogen on leaves to reproduction on other plant parts; and (iii) compare reproduction under different environmental conditions. Reproduction was assessed by visual observations of fruiting bodies on symptomatic plant parts.

\section{Materials and Methods}

The experiments were done at the Clemson University Coastal Research and Education Center in Charleston, SC, USA $\left(32^{\circ} 47^{\prime} 30.4 \mathrm{~N} ; 80^{\circ} 4^{\prime} 11.16 \mathrm{~W}\right)(15)$. Eighteen cucurbit cultivars were selected to represent diversity of 17 horticultural types, 11 taxa, 9 species, 5 genera, 3 subtribes, 2 tribes, and 1 subfamily of the Cucurbitaceae (23) (Table 1). Cultivars that had resistance to powdery mildew were selected when possible (15). To increase the genetic diversity of the species examined, two cultivars of five commonly cultivated species (Cucumis melo, C. sativus, Cucurbita maxima, C. moschata, and Citrullus lanatus) were included. Four cultivars of Cucurbita pepo were included, because of the greater variety of horticultural types within this species.

The experimental design was a randomized complete block with five replications in 2008 and four replications in 2009 and 2011. Only two blocks of 'Hubbard' were planted in 2011 due to poor seed germination. The fields of Yonges loamy fine sand (fineloamy, mixed, active, thermic Typic Endoaqualfs) were fallow in spring in 2008 and 2009 and had been cropped to crimson clover (Trifolium incarnatum) in winter 2011. Plots were single rows of raised beds shaped $0.9 \mathrm{~m}$ wide on 3.6- $\mathrm{m}$ centers covered with white-on-black polyethylene mulch. Plots were $9.1 \mathrm{~m}$ long with 2.4 $\mathrm{m}$ of nonplanted space between plots within rows. Cucurbits were transplanted on 31 July 2008, 21 July 2009, and 29 March 2011. Seven plants were spaced $1.2 \mathrm{~m}$ apart within plots. Weeds, insects, powdery mildew, and downy mildew were managed with recommended practices, which included herbicides, insecticides, and fungicides $(16,18)$. Fruit were removed from cucumber, melons, and summer squashes to delay plant senescence.

In all years, crowns of plants were inoculated twice with a 1:1 mixture of two isolates of $D$. bryoniae from South Carolina, one isolate from muskmelon (isolate C154B-R in all 3 years) and one from watermelon (isolate HD10 in 2008 and isolate W534 in 2009 and 2011). A suspension of $5 \times 10^{5}$ spores per milliliter of $0.1 \%$ sucrose- $0.05 \%$ hydrolyzed casein solution was applied with a $\mathrm{CO}_{2}$-powered backpack sprayer on 16 September and 8 October 2008 and 17 and 31 August 2009. On 10 and 21 May 2011, crowns were inoculated with a mycelial suspension prepared in sucrosecasein. In 2008, overhead irrigation was applied just prior to inoculation and a few times per week after inoculation to provide additional leaf wetness to create conditions conducive for disease development and fruiting body formation (31). In 2009 and 2011, plants were misted in the morning and evening starting at the first inoculation until 4 weeks after the second inoculation. An overhead mini-wobbler mist system (Senninger Irrigation, Clermont, FL) was run for two 30-min periods beginning at 7 P.M. and 7 A.M. in 2009 and for four 15-min periods at 7 P.M., 11 P.M., 3 A.M., and 7 A.M. in 2011 (15).

At the initial sampling on 18 September 2008, symptomatic leaves on each plant in each block were checked in the field with a $10 \times$ hand lens for the presence of fruiting bodies of D. bryoniae. Leaves were collected from all nine Cucurbita cultivars, bottle gourd, and loofah in three blocks on 23 to 24 September and 30 September to 1 October. These 11 cultivars were selected initially to check the accuracy of field observations, because disease severity was lower on these cultivars than on watermelon, melon, and cucumber (15). Subsequently, three to five (or rarely two to six) symptomatic leaves were collected from all cultivars on 15 October 2008; 22 September and 14 October 2009; and 8, 14 to16, and 23 June 2011. Five (or fewer if fewer symptomatic pieces were found in a plot) symptomatic pedicels (male flower stalks), peduncles (fruit stems), petioles, tendrils, or pieces of vines were collected on 24 to 25 October and 4 to 5 November 2009; and 8 to 9 June, 13 and 16 June, and 29 June and 1 July 2011. Plant parts other than leaves were not examined in 2008. At each sampling time, leaves or plant parts were collected from one block. A sample was defined as one plant part of one cultivar collected from one block. Diseased plant parts were incubated with a moistened paper towel in sealed plastic bags and examined at $30 \times$ magnification after $24 \mathrm{~h}$ (range 0 to $48 \mathrm{~h}$ at a few sampling times). The presence or absence and type of fruiting bodies, pseudothecia, pycnidia, or both, were recorded for each leaf. The type of fruiting bodies was recorded as primarily ( 90\%) pseudothecia, pycnidia, or both ( $>10 \%$ of each type).

In 2008 and 2009, symptomatic pedicels, peduncles, petioles, tendrils, and vine sections were cultured to recover D. bryoniae to verify that the symptoms and signs observed were gummy stem blight. Plant parts were collected from one replication on 21 and 24 November 2008 and from three replications on 29 September, 28 and 30 October, and 3 November 2009, one replication per monthly sampling. Symptomatic plant parts were collected from all cultivars except Cheese winter squash, which had no symptoms, in 2008 (15). Pieces were cut from 5 to 10 individual pedicels, peduncles, petioles, and tendrils, and 5 to 10 (2009) or 10 to 30 (2008) vine sections (one piece per plant part). Pieces were surface

Table 1. Cucurbit taxa and cultivars inoculated with Didymella bryoniae in the field in autumn 2008, autumn 2009, and autumn 2011 in Charleston, SC

\begin{tabular}{|c|c|c|c|c|}
\hline Genus & Species & Subspecific taxon $^{\mathrm{z}}$ & Cultivar & Horticultural type \\
\hline Citrullus & lanatus & var. lanatus & Crimson Sweet & Watermelon \\
\hline Citrullus & lanatus & var. lanatus & Mickey Lee & Watermelon \\
\hline Citrullus & lanatus & var. citroides & Ojakkyo & Citron \\
\hline Cucumis & melo & subsp. melo & Athena & Muskmelon \\
\hline Cucumis & melo & subsp. melo & Rocio & Honeydew \\
\hline Cucumis & sativus & None & Marketmore & Slicing cucumber \\
\hline Cucumis & sativus & None & Colt & Pickling cucumber \\
\hline Cucurbita & argyrosperma & subsp. argyrosperma & Green Striped Cushaw & Winter squash \\
\hline Cucurbita & maxima & None & Hubbard & Winter squash \\
\hline Cucurbita & maxima & None & Big Max & Giant pumpkin \\
\hline Cucurbita & moschata & None & Bugle & Butternut squash \\
\hline Cucurbita & moschata & None & Cheese & Winter squash \\
\hline Cucurbita & реро & subsp. pepo & Aladdin & Pumpkin \\
\hline Cucurbita & реро & subsp. pepo & Judgment III & Zucchini squash \\
\hline Cucurbita & реро & subsp. ovifera & Lioness & Yellow summer squash \\
\hline Cucurbita & реро & subsp. ovifera & Taybelle PM & Acorn squash \\
\hline Luffa & aegyptica & None & None & Smooth loofah \\
\hline Lagenaria & siceraria & subsp. siceraria & None & Bottle gourd \\
\hline
\end{tabular}

${ }^{\mathrm{z}}$ According to Robinson and Decker-Walters (23). 
disinfested in $0.5 \%$ sodium hypochlorite for $1 \mathrm{~min}$, rinsed in sterile distilled water, blotted, and placed onto one-quarter-strength potato dextrose agar amended with streptomycin, chloramphenicol, and metalaxyl as described previously (11). Fungi growing from the plant tissue were examined and identified $(15,17,22)$. Isolations were not done in 2011.

To estimate the density of fruiting bodies on diseased plant parts, pieces with numerous fruiting bodies were selected. In 2008 and 2009, leaves from 'Rocio,' 'Green Striped Cushaw,' Hubbard, 'Big Max,' 'Aladdin,' 'Mickey Lee,' bottle gourd, and loofah were examined on 30 September and 16 October 2008 and 22 September and 6 November 2009. Fruiting bodies on a $0.5 \times 0.5 \mathrm{~cm}$ area $\left(0.25 \mathrm{~cm}^{2}\right)$ of a leaf were counted at $40 \times$. In 2011, when the number of leaf spots was low on Cucurbita cultivars, bottle gourd, and loofah, leaves of all four watermelon and melon cultivars were examined on 14 and 24 June and 6 July. In addition, fruiting bodies were counted on $1.0 \times 0.1 \mathrm{~cm}$ sections of pedicels (flower stalks), petioles, and tendrils from 'Athena' on 1 and 6 July, and on sections of pedicles from Hubbard, Big Max, 'Cheese,' Aladdin, and bottle gourd on 14 and 29 June. At each sampling time, one area was counted on each of two replicate pieces per cultivar.

Statistical analysis. The proportions of plant parts from which $D$. bryoniae was recovered and on which fruiting bodies were observed were analyzed with SAS PROC CATMOD for categorical data, which produces a $\chi^{2}$ statistic to evaluate treatment effects. A categorical analysis was chosen because the numbers of plant parts sampled differed among cultivars and type of plant part. For example, the bush-type cultivars Judgment III and Lioness do not produce vines. Proportions were transformed by calculating the logit, and the linear model parameters were estimated using the maximum likelihood option. In order to get models that included zero values for some categories to converge (i.e., arrive at a unique solution), observed proportions were replaced with a Bayes estimator calculated as $x=(c t+k / r) * n /(n+k)$, where $x=$ the transformed proportion, $c t=$ count of plants with (or without) $D$. bryoniae, $r=$ 2 (for a binary response), $k=$ a constant, which was set equal to $r$, and $n=$ total number of plants (24). Because of this transformation, proportions of 1.0 were replaced with 0.84 , and proportions of 0.0 were replaced with 0.16 . In data tables, both back-transformed proportions and nontransformed percentages are shown.

Stepwise model reduction was done to improve the sensitivity of the analysis. The likelihood ratio was used to assess goodness of fit of various models. When factors had a $\chi^{2}$ probability of $\geq 0.10$, they were excluded from the model to increase the population size for the remaining factors, which improved the robustness of the analysis. Contrast statements were written to compare years, sampling times, plant parts, cultivars, species, or genera when treatment effects were significant $(P<0.05)$. When there were no differences $(P<$ 0.05 ) between cultivars within species, contrasts focused on comparisons among species or genera. Proportions were generated using the predict option to back-transform logit values. Pearson's correlation coefficients were calculated between the proportions of fruiting bodies on the leaves of the 18 cultivars in each year with gummy stem blight incidence and severity reported previously (15).

\section{Results}

Recovery of $\boldsymbol{D}$. bryoniae. In 2008, because symptoms of gummy stem blight appeared on crowns and leaves $\leq 1$ week after the first inoculation, it is likely that some of the symptoms resulted from natural inoculum. In 2009, symptoms were present on crowns and leaves within 3 weeks of the first inoculation. However, in 2011, symptoms were present on only a few leaves in one to four blocks and on crowns in zero to four blocks for each cultivar 10 days after the second inoculation (15).

After fruiting bodies of $D$. bryoniae were found on plant parts other than leaves in 2008, 512 symptomatic pieces of diseased cucurbit plants were cultured to verify that the symptoms were caused by this pathogen. (Recovery of $D$. bryoniae from leaves was reported previously [15]). There was no interaction of cultivar by plant part and no differences in recovery among the 17 cultivars
$(P \geq 0.27)$. Cheese winter squash was not included because no symptomatic plant parts were found. Percent recovery among the 55 peduncles, 144 petioles, 28 tendrils, or 285 pieces of vines, crowns, or stems cultured did not differ significantly $(P \leq 0.03)$. $D$. bryoniae grew from $\geq 66 \%$ of the pieces in each sample (one plant part of one cultivar from one block). Mean percent recovery was $96.9 \pm 1.3 \%$.

In 2009, 1,040 pieces of diseased plant parts were cultured. Over half of these pieces had fruiting bodies of $D$. bryoniae on them. $D$. bryoniae was recovered from 20 to $100 \%$ of the pieces in all 128 samples. Mean percent recovery of $D$. bryoniae from 356 petioles $(94.6 \pm 2.0 \%)$ was greater than from the 246 pedicels or peduncles $(78.4 \pm 4.3 \%)$ and the 246 tendrils $(88.0 \pm 2.6 \%)(P<0.0001$ and 0.02 , respectively). Percent recovery from 192 vine pieces $(93.6 \pm$ $1.9 \%$ ) did not differ from the other plant parts. There was no interaction of cultivar by plant part and no differences in recovery among the 18 cultivars $(P \geq 0.27)$.

Fruiting bodies on leaves. Fruiting bodies of $D$. bryoniae were present in each year on some leaves of all cultivars except 'Bugle' in 2008 and Hubbard and loofah in 2011 (Table 2). When data from all cultivars and all 3 years were combined, the effects of cultivar and year were highly significant $(P<0.0001)$ without a year-by-treatment interaction $(P=0.47)$. More leaves had fruiting bodies in 2009, 78.2 $\pm 3.4 \%$, than in $2008,43.8 \pm 2.2 \%$, and 2011 , $40.6 \pm 2.9 \%(P<0.0001)$.

In 2008 , leaves at the first sampling time were examined in the field for the presence of fruiting bodies of $D$. bryoniae. Leaves at the remaining sampling times were examined in the laboratory. Location (field or laboratory) did not affect the proportion of leaves with fruiting bodies (chi-square, $P=0.96$ ), and there was no cultivar-by-location interaction. Mean percentage of leaves with fruiting bodies was $28 \pm 3.9 \%$ in the field and $30 \pm 4.7 \%$ in the laboratory. Because there was no difference between locations, all subsequent observations were done only in the laboratory.

In 2008 , leaves with fruiting bodies were more commonly detected at the last sampling on 15 to 16 October, 1 week after the second inoculation, than at the previous samplings between 18 September and 1 October (chi-square, $P=0.005$ ). Only at the last sampling were fruiting bodies detected on leaves of 'Colt,' 'Taybelle PM,' and 'Lioness.' All examined leaves of watermelon, citron, and Athena muskmelon had fruiting bodies at each sampling, i.e., $100 \%$ frequency.

In 2008 , the two watermelon cultivars, 'Ojakkyo' citron, and Athena muskmelon had the highest mean percentages of leaves with fruiting bodies, significantly higher than all other cultivars except Rocio honeydew, loofah, and Green Striped Cushaw squash (chi-square contrasts, $P \leq 0.01$ ) (Table 2). Cucumbers, the other squashes, and bottle gourd had the lowest percentages of leaves with fruiting bodies and did not differ from each other. No fruiting bodies were detected on any Bugle leaves sampled. There were no differences between cultivars within species. Based on preplanned contrasts among species, watermelon had more leaves with fruiting bodies than cucumber, all four Cucurbita species, bottle gourd, and loofah $(P \leq 0.0007)$. More leaves of Cucumis melo had fruiting bodies than did C. sativus, Cucurbita maxima, C. moschata, C. pepo, and $L$. aegyptica $(P \leq 0.003)$. L. aegyptica and $C$. argyrosperma had more leaves with fruiting bodies than Cucumis sativus, Cucurbita moschata, and $C$. pepo $(P<0.003)$. The genus Citrullus had significantly more leaves with fruiting bodies than the genera Luffa, Lagenaria, and Cucurbita, and Luffa had more leaves with fruiting bodies than the mean for the genus Cucurbita (chi-square, $P \leq 0.0001$ ).

In 2009, there were no significant differences among cultivars in the occurrence of fruiting bodies on leaves. Percentages of leaves with fruiting bodies ranged from $100 \%$ for 'Crimson Sweet' and Mickey Lee watermelon, Ojakkyo citron, and Marketmore cucumber to $56 \%$ for Taybelle PM acorn squash (Table 2). The difference between the largest and smallest means was less than the differences between means judged to be significantly different in the other 2 years. 
Despite sparse development of gummy stem blight on leaves of all cucurbits in 2011, D. bryoniae again sporulated frequently on cultivars that were judged susceptible in the previous years (Table 2). The four watermelon and melon cultivars had more leaves with fruiting bodies than Hubbard, Green Striped Cushaw, Cheese, Aladdin, Taybelle PM, and Lioness squashes $(P \leq 0.01)$. A striking difference compared to the other years was that fruiting bodies were not found on leaves of loofah or Hubbard. Another difference from 2008 was that Judgment III zucchini was not significantly different from the most susceptible cultivars (Table 2).

As in 2008, watermelon in 2011 had more leaves with fruiting bodies than cucumber, all four Cucurbita species, bottle gourd, and loofah (preplanned species contrasts, $\chi^{2}, P<0.01$ ). Cucumis melo had more leaves with fruiting bodies than Cucurbita maxima, $C$. moschata, C. pepo, Lagenaria siceraria, and Luffa aegyptica $(P \leq$ 0.01). There were no differences among Cucurbita species or between Cucumis species. The genus Citrullus had significantly more leaves with fruiting bodies than the genera Luffa, Lagenaria, and Cucurbita $(P<0.01)$.

When the 936 observations were combined across years, cultivars and species sorted into mean separation groups with less overlap between groups than when individual years were examined. Crimson Sweet and Mickey Lee watermelon, Athena muskmelon, Ojakkyo citron, and Rocio honeydew had the greatest percentages of leaves with fruiting bodies of $D$. bryoniae, significantly more than all other cultivars except Green Striped Cushaw and loofah $(P$ $\leq 0.01$ ) (Table 2). Citron did not differ from the watermelon cultivars. The four Cucurbita pepo cultivars, both C. moschata cultivars, cucumbers, both $C$. maxima cultivars, and bottle gourd had the lowest percentages of leaves with fruiting bodies and did not differ from each other. There were no significant differences between cultivars within species. The genus Citrullus had significantly more leaves with fruiting bodies than the genera Luffa, Lagenaria, and Cucurbita, and Luffa had more leaves with fruiting bodies than the mean for the genus Cucurbita $(P \leq 0.0001)$.

The proportion of leaves with fruiting bodies was highly correlated with leaf disease severity in $2008(r=0.778, P=0.0004)$ and with incidence of plants with leaf symptoms in $2009(r=0.633, P$ $=0.005$ ) but not with leaf disease severity in 2011 (15). There also was a strong, positive correlation between proportions of leaves with fruiting bodies in 2008 and $2011(r=0.723, P=0.0007)$ and a weak correlation between leaf proportions in 2009 with 2008 and 2011 ( $r=0.487$ and 0.497 , respectively, $P \leq 0.04$ ).

Fruiting bodies on other plant parts. When symptomatic plant parts were collected, some were still green, while others were entirely bleached or dry. In 2009, there were no significant differences for peduncles or vines in the proportions of green and dry pieces with fruiting bodies of $D$. bryoniae. However, a slightly greater proportion of dry petioles $(79.6 \pm 4.6 \%)$ had fruiting bodies than green petioles $(62.0 \pm 5.7 \%)$ (chi-square, $P=0.02)$. In 2011, there were no significant differences for petioles, tendrils, or vines in the proportions of green and dry pieces with fruiting bodies. Thus, in subsequent analyses, both green and dry plant parts were included, and no distinction was made between them.

In 2009 and 2011, fruiting bodies of D. bryoniae were present on some of the 237 pedicels, 96 peduncles, 496 petioles, 279 tendrils, and 223 pieces of vines collected (Fig. 1). Proportions were greater in 2009 than in 2011 for all cultivars (Table 3). The mean proportion for $2009,0.752 \pm 0.018$, was greater than the mean for $2011,0.360 \pm 0.018(P<0.0001)$. In 2009, there were no differences among cultivars, the five plant parts, or sampling times $(P \geq$ 0.24 ) in the proportions of 600 pieces with fruiting bodies. Percentage of pieces with fruiting bodies ranged from 53\% on Ojakkyo citron to $97 \%$ on Green Striped Cushaw squash (Table 3).

In 2011, the proportions of 731 plant parts with fruiting bodies differed by cultivar and plant part ( $P=0.02$ and 0.001 , respectively). Athena had more fruiting bodies than eight other cultivars in seven different species, including bottle gourd, loofah, Judgment III, Cheese, Bugle, Green Striped Cushaw, Colt, and Ojakkyo $(P \leq 0.01)$ (Table 3). In addition, Rocio honeydew and Lioness yellow summer squash had a significantly greater proportion of fruiting bodies than loofah and Judgment III zucchini. Fruiting bodies occurred more frequently on pedicels (0.47) than on petioles (0.32) and tendrils (0.30). The proportions of fruiting bodies on peduncles $(0.45)$ and vines $(0.45)$ were intermediate and did not differ from the proportions on petioles or tendrils. No fruiting bodies were observed on tendrils of Colt, Green Striped Cushaw, and Lioness or on petioles of Ojakkyo and bottle gourd collected from two or three blocks.

There was no year-by-cultivar interaction for the proportion of plant parts with fruiting bodies $(P=0.27)$, but cultivar means cal-

Table 2. Frequency of occurrence of fruiting bodies of Didymella bryoniae on leaves of 18 cultivars of cucurbits grown in the field

\begin{tabular}{|c|c|c|c|c|c|c|c|c|c|c|c|c|}
\hline \multirow[b]{2}{*}{ Cultivar $^{v}$} & \multicolumn{3}{|c|}{ Fall 2008} & \multicolumn{3}{|c|}{ Fall 2009} & \multicolumn{3}{|c|}{ Spring 2011} & \multicolumn{3}{|c|}{ Mean across years ${ }^{u}$} \\
\hline & $\mathbf{N}^{\mathbf{w}}$ & $\%^{x}$ & Proportion $^{y}$ & $\mathbf{N}$ & $\%$ & Proportion & $\mathbf{N}$ & $\%$ & Proportion & $\mathbf{N}$ & $\%$ & Proportion \\
\hline Crimson Sweet & 26 & 100 & $0.844 \mathrm{a}^{\mathrm{z}}$ & 10 & 100 & 0.857 & 17 & 88 & $0.771 \mathrm{a}$ & 53 & 96.2 & $0.823 \mathrm{a}$ \\
\hline Mickey Lee & 26 & 100 & $0.844 \mathrm{a}$ & 10 & 100 & 0.857 & 19 & 84 & $0.747 \mathrm{a}$ & 55 & 94.5 & $0.813 \mathrm{a}$ \\
\hline Ojakkyo & 27 & 96 & $0.826 \mathrm{a}$ & 10 & 100 & 0.857 & 17 & 47 & $0.482 \mathrm{abc}$ & 54 & 81.5 & $0.724 \mathrm{ab}$ \\
\hline Athena & 22 & 93 & $0.819 \mathrm{a}$ & 10 & 90 & 0.786 & 19 & 74 & $0.664 \mathrm{ab}$ & 51 & 85.7 & $0.755 \mathrm{a}$ \\
\hline Rocio & 27 & 70 & $0.654 \mathrm{ab}$ & 9 & 100 & 0.847 & 17 & 76 & $0.682 \mathrm{ab}$ & 53 & 77.4 & $0.696 \mathrm{abc}$ \\
\hline Marketmore & 24 & 4 & $0.195 \mathrm{~d}$ & 10 & 100 & 0.857 & 17 & 41 & $0.440 \mathrm{abc}$ & 51 & 35.3 & $0.407 \mathrm{~d}$ \\
\hline Colt & 24 & 12 & $0.225 \mathrm{~cd}$ & 6 & 100 & 0.800 & 17 & 29 & $0.355 a b c$ & 47 & 28.6 & $0.353 \mathrm{~d}$ \\
\hline Green Striped Cushaw & 34 & 46 & $0.538 \mathrm{abc}$ & 9 & 78 & 0.693 & 11 & 9 & $0.239 \mathrm{c}$ & 54 & 50.0 & $0.503 \mathrm{bcd}$ \\
\hline Hubbard & 33 & 46 & $0.382 \mathrm{bcd}$ & 8 & 87 & 0.761 & 6 & 0 & $0.200 \mathrm{c}$ & 47 & 38.3 & $0.423 \mathrm{~d}$ \\
\hline Big Max & 21 & 46 & $0.373 \mathrm{bcd}$ & 7 & 100 & 0.819 & 16 & 19 & $0.291 \mathrm{bc}$ & 44 & 36.4 & $0.414 \mathrm{~d}$ \\
\hline Bugle & 32 & 0 & $0.164 \mathrm{~d}$ & 8 & 87 & 0.781 & 16 & 25 & $0.336 \mathrm{bc}$ & 56 & 19.6 & $0.301 \mathrm{~d}$ \\
\hline Cheese & 31 & 17 & $0.248 \mathrm{~cd}$ & 8 & 87 & 0.761 & 16 & 13 & $0.254 \mathrm{c}$ & 55 & 27.7 & $0.324 \mathrm{~d}$ \\
\hline Aladdin & 32 & 17 & $0.284 \mathrm{~cd}$ & 7 & 100 & 0.819 & 15 & 7 & $0.210 \mathrm{c}$ & 54 & 25.5 & $0.333 \mathrm{~d}$ \\
\hline Judgment III & 29 & 12 & $0.247 \mathrm{~cd}$ & 6 & 83 & 0.722 & 12 & 25 & $0.339 \mathrm{abc}$ & 47 & 25.9 & $0.331 \mathrm{~d}$ \\
\hline Lioness & 31 & 12 & $0.212 \mathrm{~d}$ & 6 & 67 & 0.600 & 16 & 13 & $0.254 \mathrm{c}$ & 53 & 17.0 & $0.269 \mathrm{~d}$ \\
\hline Taybelle PM & 32 & 13 & $0.221 \mathrm{~d}$ & 9 & 56 & 0.567 & 13 & 8 & $0.236 \mathrm{c}$ & 54 & 16.7 & $0.282 \mathrm{~d}$ \\
\hline Loofah & 32 & 64 & $0.549 \mathrm{abc}$ & 8 & 100 & 0.836 & 18 & 0 & $0.152 \mathrm{c}$ & 58 & 44.8 & $0.466 \mathrm{~cd}$ \\
\hline Bottle gourd & 23 & 50 & $0.447 \mathrm{bcd}$ & 9 & 89 & 0.773 & 18 & 22 & $0.305 \mathrm{bc}$ & 50 & 44.0 & $0.454 \mathrm{~d}$ \\
\hline
\end{tabular}

u Cultivar-by-year interaction was not significant (chi-square, $P=0.47$ ).

v Cultivars are listed in the same order as in Table 1.

${ }^{\mathrm{w}}$ Number of samples collected and observed.

x Percentages of leaves with $D$. bryoniae are means of nontransformed data.

y Proportions of leaves with $D$. bryoniae were back-transformed from the logit of proportions in categorical data analysis. Because a Bayes estimator was used in the analysis in place of the actual proportions, proportions $>0.84$ correspond to 1.0 ( $100 \%$ occurrence), and proportions $\leq 0.20$ correspond to 0.0 (no fruiting bodies found).

${ }^{\mathrm{z}}$ Means within a column with the same letter are not significantly different based on contrasts of maximum likelihood estimates evaluated with chi-square tests, $P \leq 0.01$. 
culated across years differed $(P=0.035)$. The mean proportions of plant parts with fruiting bodies was greater on Athena muskmelon than on Bugle butternut squash, Judgment III zucchini, bottle gourd, and Ojakkyo citron $(P \leq 0.01)$ (Table 3$)$. In addition, citron had fewer tissue pieces with fruiting bodies than seven other cultivars, including the watermelon cultivars, Colt cucumber, Aladdin pumpkin, and Hubbard, Lioness, and Taybelle PM squashes. Frequency of fruiting body occurrence did not differ among plant parts $(P=0.12)$.

To compare the proportions of leaves with fruiting bodies of $D$. bryoniae to other plant parts (vines, petioles, pedicels, and tendrils), data were combined in an additional analysis. (Pedicels and peduncles were considered as one tissue type because the sample size for peduncles was small.) In the combined data set, there were significant interactions between year and cultivar $(P=0.03)$ and year and plant part $(P=0.01)$. Analyzing the data for each genus separately eliminated all interactions among year, cultivar, and plant part. For Citrullus, more leaves had fruiting bodies than petioles, tendrils, and vines $(P \leq 0.01)$, and watermelon had more plant parts with fruiting bodies $(0.625)$ than citron $(0.460)(P=0.001)$. For Cucumis, plant parts did not differ, and melon had more plant parts with fruiting bodies (0.660) than cucumber (0.532) $(P=$ 0.003). For Cucurbita, more pedicels and peduncles had fruiting bodies than leaves, petioles, or tendrils, and cultivars did not differ (Fig. 1). (Vines were excluded from the analysis for Cucurbita, because few vines were examined in 2011.) For Lagenaria and Luffa there were no differences among plant parts. For all five genera, there was a highly significant difference between years, because a greater proportion of plant parts had fruiting bodies in 2009 than in 2011 (Fig. 2).

Type of fruiting bodies. In 2009 and 2011, proportions of leaves and other plant parts with only pseudothecia or only pycnidia of $D$. bryoniae did not differ among cultivars $(P \geq 0.37)$. However, when proportions included all leaves with pseudothecia (or pycnidia), i.e., the sum of leaves with only pseudothecia (or pycnidia) plus leaves with both types of fruiting bodies, significant differences among years or cultivars were observed, as explained below.

The proportion of leaves with pseudothecia differed among cultivars in 2011 (chi-square, $P=0.0007)$, but not in $2009(P=$ 0.17). In general, the differences among cultivars in 2011 were similar to differences already reported when all fruiting bodies were analyzed together: cultivars of watermelon and melon had more leaves with pseudothecia than Cucurbita cultivars (data not shown). The proportion of symptomatic leaves with pycnidia or with both types of fruiting bodies did not differ among cultivars in either year $(P=0.95$ and 0.26 , respectively).

On leaves, both pseudothecia and pycnidia were more prevalent in 2009 than in $2011(P<0.0001)$ (Fig. 2). In 2009, pycnidia were detected more frequently at sampling two than at sampling one, $93.2 \%$ of leaves compared to $20.8 \%$ ( $P<0.0001)$, but pseudothecia were detected more frequently at sampling one than at sampling two, $77.6 \%$ of leaves compared to $44.8 \%(P=0.0014)$. In 2011, there were no differences between samplings in the proportions of leaves with either type of fruiting body.

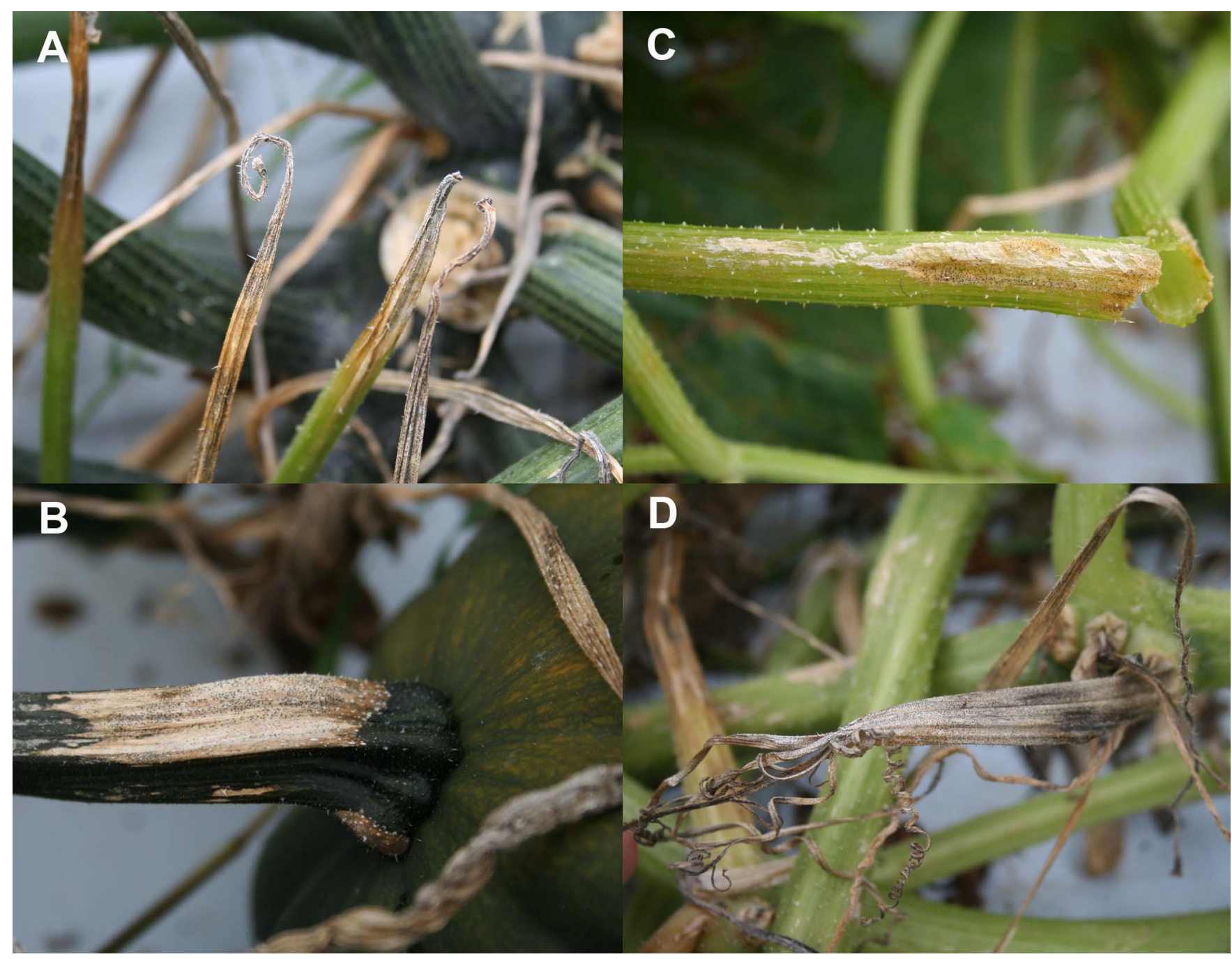

Fig. 1. Fruiting bodies, primarily pseudothecia, on diseased plant parts in fall 2009. A, Pedicel (stalk of abscised male flower) on zucchini, Cucurbita pepo 'Judgment III.' B, Peduncle (fruit stalk) on acorn squash, Cucurbita pepo 'Taybelle PM.' C, Petiole on Hubbard squash, Cucurbita maxima 'Hubbard.' D, Tendril on giant pumpkin, Cucurbita maxima 'Big Max. 
The frequency of pseudothecia or pycnidia present on plant parts other than leaves, i.e., vines, petioles, pedicels, peduncles, and tendrils, did not differ among the 18 cultivars or among the five plant parts $(P \geq 0.11)$. However, the proportion of plant parts with pseudothecia differed greatly between years $(P<0.0001)$. Pseudothecia were present on a mean of $81.5 \pm 2.5 \%$ of 268 tissue pieces examined in 2009 but on only $26.7 \pm 1.6 \%$ of 370 pieces examined in 2011 (Fig. 2).

Density of fruiting bodies. The number of fruiting bodies of $D$. bryoniae per area was counted in leaf lesions on Rocio, Green Striped Cushaw, Hubbard, Big Max, Aladdin, Mickey Lee, loofah, and bottle gourd in 2008 and 2009. The year-by-cultivar interaction was significant $(P=0.03)$, because there were some differences among cultivars in $2008(P=0.01)$ but not in $2009(P=0.67)$. In 2008 , Rocio honeydew $\left(124 / 0.25 \mathrm{~cm}^{2}\right)$ and Mickey Lee watermelon $\left(88 / 0.25 \mathrm{~cm}^{2}\right)$ had more fruiting bodies than Green Striped Cushaw (8/0.25 $\left.\mathrm{cm}^{2}\right)$ and bottle gourd $\left(20 / 0.25 \mathrm{~cm}^{2}\right)$. In 2009 , the mean across all eight cultivars was 136 fruiting bodies $/ 0.25 \mathrm{~cm}^{2}$ leaf area.

In 2011, when the number of leaf spots was low, fruiting bodies were counted on leaves of the four watermelon and melon cultivars, which were the cultivars most susceptible to gummy stem blight (15). Athena muskmelon leaves had fewer fruiting bodies, $98 / 0.25 \mathrm{~cm}^{2}$, than watermelon or honeydew leaves $(P \leq 0.005)$, which did not differ from each other over a range of 164 to $183 / 0.25 \mathrm{~cm}^{2}$. Fruiting bodies also were counted on dried pedicels, petioles, and tendrils collected from Athena, and counts were compared to counts on leaves of Athena. There was no significant difference among plant parts $(P=0.07)$, with a mean of 258 fruiting bodies $/ 0.25 \mathrm{~cm}^{2}$. Finally, counts of fruiting bodies on dried pedicels of Hubbard, Big Max, Cheese, Aladdin, and bottle gourd did not differ among cultivars $(P=0.46)$, with a mean of 138 fruiting bodies $/ 0.25 \mathrm{~cm}^{2}$.

\section{Discussion}

D. bryoniae was able to reproduce on all parts of all 18 cultivars examined in this study. More watermelon, melon, and citron leaves had fruiting bodies of $D$. bryoniae than leaves of most other horticultural types and species. Although the 2008 and 2011 growing seasons had different mean temperatures and amounts of rainfall, cultivars sorted in the same general order in both years (15). Because there was no interaction between year and cultivar, the greater proportion of leaves with fruiting bodies on Citrullus lanatus and Cucumis melo compared to C. sativus, Cucurbita spp., and $L$. siceraria is a general result expected to occur under most growing conditions.

Differences among cultivars in the proportions of plant parts other than leaves (vines, pedicels, peduncles, petioles, and tendrils) that had fruiting bodies were not as pronounced as with leaves. However, one or both melon cultivars, Athena and Rocio, had many plant parts, and citron consistently had few plant parts, with fruiting bodies. As reported previously, fruiting bodies often were

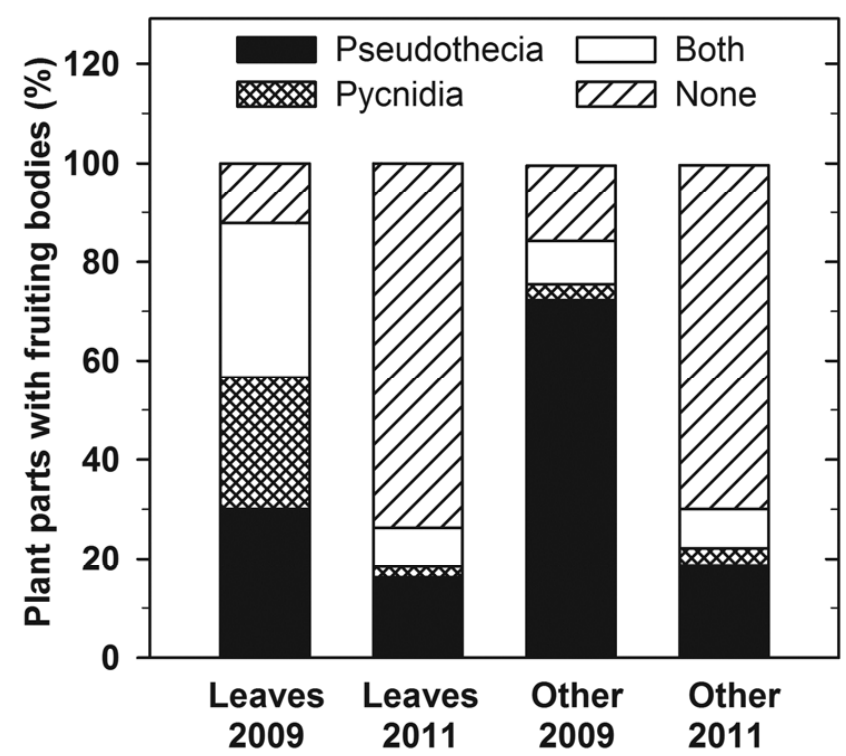

Fig. 2. Frequency of occurrence of pseudothecia, pycnidia, both fruiting bodies, and no fruiting bodies on leaves and all other plant parts (peduncles, pedicels, petioles, tendrils, and vines) in fall 2009 and spring 2011. Mean percentages were calculated from 150 and 280 observations for leaves and 268 and 370 observations for other plant parts in 2009 and 2011, respectively.

Table 3. Frequency of occurrence of fruiting bodies of Didymella bryoniae on pedicels, peduncles, petioles, tendrils, and vines of 18 cultivars of cucurbits grown in the field

\begin{tabular}{|c|c|c|c|c|c|c|c|c|c|}
\hline \multirow[b]{2}{*}{ Cultivar $^{v}$} & \multicolumn{3}{|c|}{ Fall 2009} & \multicolumn{3}{|c|}{ Spring 2011} & \multicolumn{3}{|c|}{ Mean across years ${ }^{u}$} \\
\hline & $\mathbf{N}^{\mathbf{w}}$ & $\%^{x}$ & Proportion $^{y}$ & $\mathbf{N}$ & $\%$ & Proportion & $\mathbf{N}$ & $\%$ & Proportion \\
\hline Crimson Sweet & 25 & 80 & 0.714 & 36 & 49 & $0.434 \mathrm{abc}^{\mathrm{z}}$ & 61 & 59 & $0.549 \mathrm{abc}$ \\
\hline Mickey Lee & 25 & 96 & 0.829 & 43 & 36 & $0.394 \mathrm{abc}$ & 68 & 56 & $0.554 \mathrm{abc}$ \\
\hline Ojakkyo & 39 & 53 & 0.529 & 32 & 9 & $0.239 \mathrm{bc}$ & 71 & 30 & $0.398 \mathrm{~d}$ \\
\hline Athena & 37 & 82 & 0.763 & 53 & 58 & $0.567 \mathrm{a}$ & 90 & 66 & $0.648 \mathrm{a}$ \\
\hline Rocio & 30 & 93 & 0.809 & 39 & 39 & $0.488 \mathrm{ab}$ & 69 & 56 & $0.628 a b$ \\
\hline Marketmore & 25 & 64 & 0.600 & 33 & 26 & $0.343 a b c$ & 58 & 41 & $0.454 \mathrm{abcd}$ \\
\hline Colt & 44 & 96 & 0.822 & 36 & 20 & $0.313 \mathrm{bc}$ & 80 & 58 & $0.593 a b c$ \\
\hline Green Striped Cushaw & 25 & 97 & 0.812 & 49 & 23 & $0.304 \mathrm{bc}$ & 76 & 48 & $0.484 \mathrm{abcd}$ \\
\hline Hubbard & 32 & 95 & 0.802 & 28 & 22 & $0.357 \mathrm{abc}$ & 64 & 66 & $0.607 \mathrm{abc}$ \\
\hline Big Max & 30 & 93 & 0.810 & 45 & 26 & $0.339 \mathrm{abc}$ & 75 & 51 & $0.527 \mathrm{abcd}$ \\
\hline Bugle & 27 & 81 & 0.679 & 35 & 15 & $0.289 \mathrm{bc}$ & 62 & 42 & $0.459 \mathrm{bcd}$ \\
\hline Cheese & 31 & 86 & 0.721 & 41 & 26 & $0.318 \mathrm{bc}$ & 72 & 56 & 0.492 abcd \\
\hline Aladdin & 38 & 92 & 0.803 & 47 & 36 & $0.385 \mathrm{abc}$ & 75 & 56 & $0.541 \mathrm{abc}$ \\
\hline Judgment III & 33 & 82 & 0.767 & 35 & 20 & $0.204 \mathrm{c}$ & 69 & 55 & $0.481 \mathrm{bcd}$ \\
\hline Lioness & 43 & 87 & 0.753 & 42 & 48 & $0.489 \mathrm{ab}$ & 85 & 68 & $0.623 \mathrm{abc}$ \\
\hline Taybelle PM & 27 & 93 & 0.794 & 41 & 44 & $0.439 a b c$ & 68 & 65 & $0.580 \mathrm{abc}$ \\
\hline Loofah & 48 & 95 & 0.814 & 46 & 7 & $0.212 \mathrm{c}$ & 94 & 45 & $0.519 \mathrm{abcd}$ \\
\hline Bottle gourd & 44 & 71 & 0.704 & 50 & 25 & $0.290 \mathrm{bc}$ & 94 & 45 & $0.484 \mathrm{bcd}$ \\
\hline
\end{tabular}

" Cultivar-by-year interaction was not significant $\left(\chi^{2}, P=0.21\right)$.

${ }^{v}$ Cultivars are listed in the same order as in Table 1.

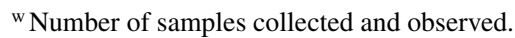

${ }^{x}$ Percentages of plant parts with $D$. bryoniae are means of nontransformed data.

y Proportions of plant parts with $D$. bryoniae were back-transformed from the logit of proportions in categorical data analysis. Because a Bayes estimator was used in the analysis in place of the actual proportions, proportions $>0.84$ correspond to 1.0 (100\% occurrence).

${ }^{\mathrm{z}}$ Means within a column with the same letter are not significantly different based on contrasts of maximum likelihood estimates evaluated with $\chi^{2}$ tests, $P \leq$ 0.01 . 
found on vines at nodes and at the bases of petioles $(2,3,5)$. Although cucumber, bottle gourd, and eight cultivars of squashes (other than Green Striped Cushaw) had smaller proportions of leaves with fruiting bodies than watermelon and melon, most of these 11 cultivars did not differ from watermelon and melon based on proportions of fruiting bodies on other plant parts.

The severity of gummy stem blight on leaves had some effect on the proportion of leaves with fruiting bodies of $D$. bryoniae. In both fall experiments, cultivars that had higher severity or incidence of foliar gummy stem blight also had more diseased leaves with fruiting bodies (15). However, the proportions of diseased leaves with fruiting bodies in 2011, when disease severity was $\leq 1$ to $4 \%$, were as great as in 2008 , when cultivars differed in disease severity, and half as great as in 2009. An alternative hypothesis to explain the cultivar differences in proportions of fruiting bodies is that cultivars with more leaf spots per leaf, as reflected in greater severity ratings, also had a greater likelihood that fruiting bodies would be found on a given leaf. However, the uniformly mild disease in 2011 disproves the alternative hypothesis. Although the number of leaf spots per leaf was not recorded, it is likely that most leaves examined in 2009 and 2011 had more than one spot and only one spot, respectively. Even if leaves had more than one spot of gummy stem blight, the second or third spots were examined only if no fruiting bodies were found on the first spot. It is possible that a metabolite found in watermelon and melon, but not in the other cucurbits in this study, promoted growth and reproduction of D. bryoniae. For example, cinnamic acid present in root exudates of watermelon is not produced by bottle gourd (20).

Two notable results were observed with Ojakkyo citron. Citron leaves were as likely as watermelon and melon leaves to have fruiting bodies, even though leaf disease severity was significantly less on citron than on the four cultivars of watermelon and melon (15). Thus, it appears that the resistance to gummy stem blight observed in citron is resistance to infection and does not reduce pathogen reproduction after establishment $(6,19)$. To verify this hypothesis, the number of fruiting bodies would have to be quantified on citron leaves; this was not done in this study, because cultivars likely to have leaf spots were selected when fruiting bodies were counted. Secondly, there was a difference in reproductive potential of citron leaves compared to other plant parts examined. On other plant parts, citron had fewer fruiting bodies than most other cultivars. Spores produced on leaves may be more likely to be dispersed than spores produced on plant parts within the canopy (25). Whether the difference between citron leaves and other plant parts has epidemiological significance is unknown.

Fruiting bodies that formed on vines and crowns were the most epidemiologically significant reproductive structures observed in this study. Schenck (25) considered pseudothecia and pycnidia on the crowns of plants to contribute significantly to secondary disease cycles during the growing season. Cankered crowns of muskmelon survived in the field $\geq 2$ years after a crop in South Carolina, so fruiting bodies on crowns and vines can serve as a primary source of inoculum for subsequent crops $(12,25,31)$. Dead leaves and other plant parts on cucurbits do not abscise as they do on other crops. Thus, necrotic tissues with fruiting bodies on them remain close to healthy tissue, which facilitates dispersal of conidia during the growing season (25). Whereas peduncles of squashes are removed with harvested fruits, peduncles of melon and watermelon are left attached to the plant at harvest. Fruiting bodies were found on peduncles left on plants in 2009 and 2011, as reported previously for greenhouse cucumber (31). However, reproduction on leaves, pedicels, petioles, and tendrils would have no or minimal epidemiological effect in subsequent years, because these nonlignified plant parts decay faster than vines $(11,12)$.

D. bryoniae primarily produced pseudothecia, but also pycnidia or both types of fruiting bodies, on all parts of all hosts. The high frequency of pseudothecia was unexpected, based on previous reports that both pycnidia and pseudothecia occurred on a variety of different cucurbits and plant parts $(3,5,7,25)$. In 2009, but not in 2011, pseudothecia were more frequent on other parts of all cucur- bits than on leaves. Schenck (25) observed more pycnidia than pseudothecia on watermelon leaves but more pseudothecia on other parts of watermelon. Approximately half of the pseudothecia examined under a compound microscope had mature ascospores (data not shown). Because ascospores are aerially dispersed, they are a means for the pathogen to reach new substrates when healthy host tissue becomes limiting, and the fungus needs additional food resources. In addition, because ascospores are more tolerant of fungicides than conidia, dispersal of ascospores could be a mechanism for spread of fungicide-insensitive isolates of $D$. bryoniae (12). In some previous studies, pseudothecia were more likely to form late in the epidemic on dead plant tissues. Pseudothecia were observed on vine and crown cankers several weeks or 2 months after they were inoculated in the greenhouse or field, respectively $(2,5)$. However, in another study, pseudothecia appeared before pycnidia on inoculated stems of young cucumber plants (3). Schenck (25) observed pseudothecia on cankers on young plants and on tendrils and petioles "early in disease development." Ascospores were detected in the air when the first symptoms of gummy stem blight appeared in the field and in the greenhouse $(25,31)$. Thus, pseudothecia can form at any point during the disease cycle.

Pseudothecia were the predominant fruiting body both in the fall, when day length was $11 \mathrm{~h}$, and in early summer, when day length was longest in Charleston, SC, at $14 \mathrm{~h}$. In culture, D. bryoniae requires a 12- to 16-h photoperiod for optimal sporulation $(14,17)$. Therefore, day length probably was not the factor responsible for the preponderance of pseudothecia. Although air temperatures $>10^{\circ} \mathrm{C}$ inhibited pseudothecia production in D. rabiei, D. bryoniae produced many pseudothecia at temperatures $\geq 27^{\circ} \mathrm{C}$ in summer 2009 and $2011(15,30)$. It is possible that long periods of leaf wetness, as supplied by the mist system under moderate temperatures in fall 2009, favored pycnidia production, while short periods of leaf wetness, as in the dry, warm spring of 2011, favored pseudothecia production. Although van Steekelenburg (31) reported that moisture was required for fruiting body production by $D$. bryoniae, the association between the length of leaf wetness periods and type of fruiting body production has not been examined.

$D$. bryoniae, a necrotrophic pathogen, can reproduce on all affected tissue. Leaf spots of gummy stem blight on all cultivars are necrotic, not chlorotic. Fruiting bodies were observed only in the center of most leaf spots, regardless of the size of the spot, as previously reported $(2,5)$. The diameter of the area with fruiting bodies was usually less than half the diameter of the spot. On other plant parts that already were dead when collected, fruiting bodies generally were present on $\geq 50 \%$ of the diseased area. Because $D$. bryoniae is a necrotroph, it can continue to reproduce on dead leaves and other plant parts until they are disked under the soil, so that a large proportion of diseased plant parts eventually may support fruiting bodies $(11,12,25,31)$. It is also possible that $D$. bryoniae colonized some plant parts, like tendrils or petioles of older leaves, that were not infected and senesced before the end of the season. D. rabiei extensively colonized chickpea stems under laboratory conditions (30). Nevertheless, reproduction by $D$. bryoniae on any colonized plant parts would contribute to inoculum. The mean number of fruiting bodies averaged across all diseased plant parts and cultivars examined was $731 \pm 75(\mathrm{SE}) / \mathrm{cm}^{2}$ of diseased tissue. This value was more than six times greater than the number reported for a similar pathogen, Didymella pinodes, that produced 108 pycnidia/ $\mathrm{cm}^{2}$ on Pisum sativum (26).

There are several important conclusions from this study. (i) Watermelon, muskmelon, and honeydew melon were the hosts most suitable for the reproduction of $D$. bryoniae across environments favorable and unfavorable for disease development. (ii) Pathogen reproduction varied on different crops within the genera Cucumis, Citrullus, and Cucurbita in one or more years. Reproduction on $C$. sativus was less than on $C$. melo. Likewise, reproduction on leaves of $C$. pepo was less than on $C$. argyrosperma. Reproduction on citron was less than on watermelon. Thus, conclusions about one cucurbit species may not be valid for other species, even those within the same genus. (iii) Different plant parts sometimes sup- 
ported different levels of reproduction on different hosts. The two most striking cases were a greater proportion of leaves with fruiting bodies than other plant parts on Citrullus, and a greater proportion of Cucurbita pedicels with fruiting bodies than leaves and other plant parts. To increase the likelihood of finding pseudothecia to confirm a diagnosis of gummy stem blight, plant parts other than leaves should be examined. (iv) When environmental conditions in the fall favored development of gummy stem blight, $D$. bryoniae reproduced readily on a variety of diseased plant parts. Even when disease development was limited by unfavorable environmental conditions in spring 2011, D. bryoniae still reproduced on diseased tissue. In summary, D. bryoniae infected and reproduced on all parts of all cucurbit hosts. Occurrence of D. bryoniae on many parts of watermelon was noted in several previous reports $(1,25)$. Based on the results obtained in this study, this observation holds true for eight additional cucurbit species: Cucumis sativus, $C$. melo, Cucurbita argyrosperma, C. maxima, C. moschata, C. pepo, Luffa aegyptica, and Lagenaria siceraria. It is likely that reproduction on various plant parts contributes to the rapid increase in gummy stem blight severity on susceptible crops under conducive environmental conditions $(9,10,15)$.

\section{Acknowledgments}

I thank E. L. Fillippeli, V. B. DuBose, G. V. Baccari, A. W. Lassiter, and J. A. Dufault for technical assistance and J. R. Rieck, Department of Mathematics, Clemson University, for statistical advice.

\section{Literature Cited}

1. Chester, F. D. 1891. Notes on three new or noteworthy diseases of plants. Bull. Torrey Bot. Club 18:371-374.

2. Chiu, W. F., and Walker, J. C. 1949. Physiology and pathogenicity of the cucurbit black-rot fungus. J. Agric. Res. 78:589-615.

3. de Neergaard, E. 1989. Studies of Didymella bryoniae (Auersw.) Rehm: Development in the host. J. Phytopathol. 127:107-115.

4. Govinddasamy, R., Van Vranken, R., Scairappa, W., Ayeni, A., Puduri, V. S., Pappas, K., Simon, J. E., Mangan, F., Lamberts, M., and McAvoy, G. 2010. Ethnic crop opportunities for growers on the East Coast: A demand assessment. J. Extension 48:6RIB2. Online publication.

5. Grossenbacher, J. G. 1909. A Mycosphaerella wilt of melons. New York (Geneva) Agric. Exp. Stn. Tech. Bull. 9:193-229.

6. Gusmini, G., Song, R. H., and Wehner, T. C. 2005. New sources of resistance to gummy stem blight in watermelon. Crop Sci. 45:582-588.

7. Hemmi, T. 1922. On the occurrence of Mycosphaerella wilt of muskmelon in Japan. Phytopathology 12:394-397.

8. Jensen, B. D., Massawe, A., and Swai, I. S. 2011. First report of gummy stem blight caused by Didymella bryoniae on watermelon and confirmation of the disease on pumpkin in Tanzania. Plant Dis. 95:768.

9. Keinath, A. P. 1995. Fungicide timing for optimum management of gummy stem blight epidemics on watermelon. Plant Dis. 79:354-358.

10. Keinath, A. P. 2000. Effect of protectant fungicide application schedules on gummy stem blight epidemics and marketable yield of watermelon. Plant Dis. 84:254-260.

11. Keinath, A. P. 2002. Survival of Didymella bryoniae in buried watermelon vines in South Carolina. Plant Dis. 38:32-38.

12. Keinath, A. P. 2008. Survival of Didymella bryoniae in infested muskmelon crowns in South Carolina. Plant Dis. 92:1223-1228.

13. Keinath, A. 2011. From native plants in Central Europe to cultivated crops worldwide: The emergence of Didymella bryoniae as a cucurbit pathogen. HortScience 46:532-535.

14. Keinath, A. P. 2012. Differential sensitivity to boscalid in conidia and ascospores of Didymella bryoniae and frequency of boscalid-insensitive isolates in South Carolina. Plant Dis. 96:228-234.

15. Keinath, A. P. 2014. Differential susceptibility of nine cucurbit species to the foliar blight and crown canker phases of gummy stem blight. Plant Dis 98:247-254.

16. Keinath, A. P., DuBose, V. B., and Walters, E. 2009. Susceptibility to gummy stem blight of 16 cultivars of various cucurbits, 2008. Plant Dis. Managem. Rep. 3:V036. Online publication. doi:10.1094/PDMR03

17. Keinath, A. P., Farnham, M. W., and Zitter, T. A. 1995. Morphological, pathological, and genetic differentiation of Didymella bryoniae and Phoma spp. isolated from cucurbits. Phytopathology 85:364-369.

18. Keinath, A. P., Fillippelli,, E. L., Baccari, G. V., and DuBose, V. B. 2010 Susceptibility of 15 cultivars of watermelon, melon, squash, pumpkin, and bottle gourd to gummy stem blight, 2009. Plant Dis. Managem. Rep. 4:V120. Online publication. doi:10.1094/PDMR04

19. Levi, A., Thomas, C. E., Keinath, A. P., and Wehner, T. C. 2001. Genetic diversity among Citrullus lanatus and Citrullus colocynthis accessions Genet. Res. Crop Evol. 48:559-566.

20. Ling, N., Zhang, W., Wang, D., Mao, J., Huang, Q., Guo, S., and Shen, Q. 2013. Root exudates from grafted-root watermelon showed a certain contribution in inhibiting Fusarium oxysporum f. sp. niveum. PLoS One. Online publication. doi: 10.1371/journal.pone.0063383

21. Peterson, P. D., and Campbell, C. L. 2002. Prevalence and ecological association of foliar pathogens of cucumber in North Carolina, 1996-1998. Plant Dis. 86:1094-1100

22. Punithalingam, E., and Holliday, P. 1972. Didymella bryoniae. CMI Descriptions of Pathogenic Fungi and Bacteria. No. 332. Commonwealth Mycol. Inst., Kew, England.

23. Robinson, R. W., and Decker-Walters, D. S. 1997. Cucurbits. CAB International, New York.

24. Santner, T. J., and Duffy, D. E. 1989. The Statistical Analysis of Discrete Data. Springer-Verlag, New York.

25. Schenck, N. C. 1968. Epidemiology of gummy stem blight (Mycosphaerella citrullina) on watermelon: Ascospore incidence and disease development. Phytopathology 58:1420-1422.

26. Schoeny, A., Menat, J., Darsonval, A., Rouault, F., Jumel, S., and Tivoli, B. 2008. Effect of pea canopy architecture on splash dispersal of Mycosphaerella pinodes conidia. Plant Pathol. 57:1073-1085.

27. Sitterly, W. R. 1969. Effect of crop rotation on cucumber gummy stem blight. Plant Dis. Rep. 53:417-419.

28. Smith, C. O. 1905. The study of the diseases of some truck crops in Delaware. Del. Coll. Agric. Exp. Stn. Bull. 70.

29. Sudisha, J., Niranjana, S. R., Umesha, S., Prakash, H. S., and Shekar Shetty, H. 2006. Transmission of seed-borne infection of muskmelon by Didymella bryoniae and effect of seed treatments on disease incidence and fruit yield. Biol. Control 37:196-205.

30. Trapero-Casas, A., and Kaiser, W. J. 1992. Development of Didymella rabiei, the teleomorph of Ascochyta rabiei, on chickpea straw. Phytopathology 82:1261-1266.

31. van Steekelenburg, N. A. M. 1983. Epidemiological aspects of Didymella bryoniae, the cause of stem and fruit rot of cucumber. Neth. J. Plant Pathol. $89: 75-86$

32. Zhang, J. X., Bruton, B. D., Miller, M. E., and Isakeit, T. 1999. Relationship of developmental stage of cantaloupe fruit to black rot susceptibility and enzyme production by Didymella bryoniae. Plant Dis. 83:1025-1032. 